\title{
Disfunção Cognitiva Pós-Operatória
}

As alterações cognitivas potencialmente relacionadas ao ato operatório e/ou anestésico têm preocupado diversos grupos de pesquisadores em todo o mundo.

As principais dificuldades para analisar os resultados observados advêm dos múltiplos fatores que podem contribuir ou interferir com eles.

Aparentemente a idade, o tipo de intervenção cirúrgica, a ansiedade pré-operatória, o tipo de anestesia são alguns dos fatores que interferem com o aparecimento desta complicação pós-operatória ${ }^{1}$.

Em 2002, um grupo de pesquisadores da Alemanha, publicou trabalho sobre disfunção cognitiva após anestesia geral, estudando a concentração sérica da proteína S-100 e da enolase neuronal específica (ENE) como indicador desta alteração ${ }^{2}$. O racional dessa pesquisa tinha como base o uso da proteína S-100 em cirurgia cardíaca, trauma e acidentes vasculares encefálicos como indicador de isquemia encefálica. A proteína S-100 é encontrada em astrocitos e células de Schwann e a enolase neuronal específica no citoplasma de neurônios e células neuroendócrinas. Suas concentrações séricas se alteram após lesão do sistema nervoso central bem como quando há disfunção da barreira hematoencefálica. Os pacientes foram submetidos a testes para avaliar percepção, atenção, memória associativa, coordenação visual e motora. Aconclusão do estudo indicou que a enolase neuronal específica não mostrou diferença entre os pacientes que apresentavam ou não disfunção cognitiva pós-operatória e que a proteína S-100 tinha um valor limitado pela fraca especificidade e possível contaminação extra-encefálica, já que também é produzida em outros tecidos do organismo.

Assim a perspectiva de um indicador objetivo enfraqueceu e restaram aos pesquisadores os difíceis meandros dos parâmetros subjetivos.

Àcada nova pesquisa sobre esse assunto muitas dúvidas surgem: qual é a definição de disfunção cognitiva significativa? Os testes neuropsicométricos são aprendidos pelos pacientes durante as múltiplas avaliações? Quais testes devem ser empregados ${ }^{3}$ ? A anestesia regional é preferível à anestesia geral ${ }^{4}$ ?

Não há respostas simples, nem fórmulas pré-estabelecidas, mas há que continuar pesquisando...

Nesse número da revista um grupo brasileiro acrescenta uma contribuição a esse assunto estudando prevalência e fatores associados à disfunção cognitiva pós-operatória. Convido os leitores a pensar sobre o assunto. A população do Brasil envelhece e o atendimento cirúrgico de pacientes idosos é uma realidade. Criar evidências que contribuam com as diretrizes da prática clínica é uma necessidade.
Entretanto é importante refletir que nem só a população idosa pode exibir essas alterações, a hospitalização e a anestesia ou intervenção cirúrgica podem também contribuir para alterações de desenvolvimento cognitivo, emocional e sócio-comportamental em crianças ${ }^{5}$.

Dra. Judymara Lauzi Gozzani, TSA

Editor Chefe da Revista Brasileira de Anestesiologia

\section{Postoperative Cognitive Dysfunction}

Cognitive changes potentially related to surgical and/or anesthetic procedures are worrying many research groups worldwide.

Major difficulties to analyze observed results are posed by the multiple factors, which may contribute to or interfere with them.

Seemingly age, type of procedure, preoperative anxiety and type of anesthesia are some factors interfering with this postoperative complication ${ }^{1}$.

In 2002, a group of German investigators has published a study on cognitive dysfunction after general anesthesia by studying serum concentration of S-100 protein and of specific neuronal enolase (SNE) as indicators of this change ${ }^{2}$. The rational of this research was the use of S-100 protein in cardiac surgery, trauma and strokes as the marker for brain ischemia.

S-100 protein is found in astrocytes and Schwann cells, and specific neuronal enolase is found in neuronal cytoplasm and neuroendocrine cells. Its serum concentrations are changed after brain injuries or blood brain barrier dysfunction. Patients were submitted to tests to evaluate perception, attention, associative memory, visual and motor coordination. The conclusion was that specific neuronal enolase was not different in patients with or without postoperative cognitive dysfunction and that S-100 protein is of limited value due to poor specificity and possible extra-brain contamination since it is also produced by other tissues.

So, the perspective of an indicator has grown weak and investigators were solely left with the difficult windings of subjective parameters.

At every new study on the subject more questions are asked: which is the definition of significant cognitive dysfunction? Are neuropsychometric tests learned by patients during multiple evaluations? Which tests should be applied ${ }^{3}$ ? Is regional anesthesia better than general anesthesia ${ }^{4}$ ? 
There are no simple answers or pre-established formulas, but research has to go on ...

In this edition, a Brazilian group adds a contribution to this subject by studying the prevalence and factors associated to postoperative cognitive dysfunction. I invite the readers to read the study and think about it. Brazilian population is aging and surgical management of elderly patients is a reality. Creating evidences contributing to clinical practice guidelines is a must.

However, it is important to consider that not only the elderly may present such changes; hospital admission and anesthesia or surgical procedure may also contribute for cognitive, emotional and socio-behavioral development changes in children ${ }^{5}$.

Judymara Lauzi Gozzani, TSA, M.D.

Editor-in-Chief, Brazilian Journal of Anesthesiology

\section{REFERÊNCIAS - REFERENCES}

01. Canet J, Raeder J, Rasmussen LS et al- Cognitive dysfunction after minor surgery in the elderly. Acta Anaesthesiol Scand, 2003;47:1204-1210.

02. Linstedt $U$, Meyer O, Kropp P et al - Serum concentration of S-100 protein in assessment of cognitive dysfunction after general anesthesia in different types of surgery. Acta Anaesthesiol Scand, 2002;46:384-389.

03. Heyer EJ, Connolly ES - Serum concentration of S-100 protein in assessment of cognitive dysfunction after general anesthesia in different types of surgery. Acta Anaesthesiol Scand, 2003;47:911-912.

04. Wu CL, Hsu W, Richman JM et al - Postoperative cognitive function as an outcome of regional anesthesia and analgesia. Reg Anesth Pain Med, 2004;29:257-268.

05. Caldas JC, Pais-Ribeiro JL, Carneiro SR - General anesthesia, surgery and hospitalization in children and their effects upon cognitive, academic, emotional and sociobehavioral development - a review. Paediatr Anaesth, 2004;14:910-915. 